\title{
ESSAY
}

\section{Bowers v. Hardwick: Precedent by Personal Predilection}

\author{
Thomas B. Stoddard $\dagger$
}

Conservative legal critics of Earl Warren's Supreme Court, both of its major decisions and of its general direction, are now especially powerful and vocal. Their ranks include the current attorney general of the United States and the new chief justice of the Court. The critics are not of one voice, but they often express one grievance with particular vehemence: that in rendering decisions, the Warren Court was concerned less with adherence to legal principles than with vindication of the personal views of the particular justices then sitting on the bench.

This characterization is unfair. The justices with whom the Warren Court is most closely identified-Black, Douglas, Goldberg, Brennan, Marshall, and Chief Justice Warren himself-disdained neither legal principles nor legal reasoning. Rather, they subscribed to the concept that the principles of the Constitution should not be frozen in time, but should grow in meaning as the country itself evolves. Their boldest decisions reflected that philosophy more than they expressed the personal opinions of the dominant justices.

Nevertheless, the critics of the Warren Court have helped bring to light a significant concern that liberals too often dismiss: judges do abuse their oath of office when they depart from the rules in order to achieve a result they believe to be desirable on other grounds. Courts should decide cases by reference to precedent and logic, and they should take procedure seriously.

There are instances in which the Supreme Court has done violence to this idea, but-curiously-the most flagrant example comes not from the Warren Court of the 1960s, but from the Bur-

† Executive Director, Lambda Legal Defense and Education Fund, Inc. and Adjunct Associate Professor of Law, New York University School of Law. 
ger Court of the 1980s. It is Bowers v. Hardwick, ${ }^{1}$ the decision from last summer in which the Court upheld the constitutionality of a Georgia statute criminalizing certain sex acts under the term "sodomy."

A careful review of the case, including the decisions of the two lower courts, makes clear that the Court's opinion in Hardwick rests upon nothing more substantial than the collective distaste of the five justices in the majority for the conduct under scrutiny. The opinion is, to be blunt, devoid of logic. Moreover, in order to reach its conclusion, the majority seriously distorted the nature and posture of the issue presented to the Court. Bowers v. Hardwick is judicial decision making by fiat rather than reason.

The statute under consideration in Hardwick defines sodomy as "any sexual act involving the sex organs of one person and the mouth or anus of another." The conduct can be either homosexual or heterosexual, and the participants married to one another or not. The offense is a felony, and it carries a penalty of up to twenty years in prison.

The statute was challenged in 1983 as an unconstitutional infringement of the federal constitutional right to privacy in a rather perfunctory complaint filed in the United States District Court for the Northern District of Georgia by Michael Hardwick and John and Mary Doe. Hardwick, it was alleged, was a twenty-nine-yearold "practicing homosexual, who regularly engages in private homosexual acts and will do so in the future." The Does were a lawfully married couple who sought "to engage in the [proscribed] sexual activity . . . in the privacy of their home." The complaint also alleged that Hardwick himself had already been arrested for "sodomy" in his own home, although the case had not been presented to a grand jury, and that he therefore lived "in imminent danger of arrest, prosecution and imprisonment." The Does had not been arrested, but, it was claimed, had been "chilled and deterred" from engaging in the conduct. The plaintiffs sought a declaratory judgment that the statute violated the due process clause of the fourteenth amendment and the first amendment guarantees of freedom of expression and association."

In April of 1985, the district court judge issued a terse order dismissing the complaint in total. He ruled that the Does had not

106 S.Ct. 2841 (1986).

2 Id. at 2842 n.1.

s Hardwick v. Bowers, 760 F.2d 1201, 1204 (11th Cir. 1985).

- Hardwick, 106 S.Ct. at 2842 \& n.2. 
shown that they were "in immediate danger of sustaining direct injury," and that their claim was therefore not justiciable. ${ }^{5}$ As for Hardwick, the judge concluded that his claim was "foreclosed" by Doe v. Commonwealth's Attorney, ${ }^{6}$ in which the Supreme Court had affirmed without opinion a three-judge federal district court decision upholding a Virginia "sodomy" statute."

The plaintiffs appealed the district court decision to the United States Court of Appeals for the Eleventh Circuit, and succeeded in having it overturned. The appellate panel agreed with the lower court that the Does lacked standing. But, by a vote of two to one, it reinstated the claims made by Hardwick. Doe $v$. Commonwealth's Attorney, the court said, was not controlling, largely because the case's value as precedent was unclear. More importantly, however, it ruled that Hardwick's constitutional challenge had possible merit. The court reviewed the principal Supreme Court privacy decisions, from Meyer v. Nebraska in 1923 to Akron v. Akron Center for Reproductive Health in $1983,{ }^{8}$ and determined that in sum they prevented the states "from unduly interfering in certain individual decisions critical to personal autonomy," including certain "intimate associations" such as marriage. It then drew an analogy between sex in marriage and Hardwick's desire to engage in sexual relations with another consenting adult. The "resemblance" of the two to one another, coupled with Hardwick's intent to carry out his activity in seclusion, led the court to conclude that the Georgia statute "implicate[d] a fundamental right of Michael Hardwick." The Eleventh Circuit expressed its holding as follows:

The activity [Hardwick] hopes to engage in is quintessentially private and lies at the heart of an intimate association beyond the proper reach of state regulation. ... We therefore remand this case for trial, at which time the State must prove in order to prevail that it has a compelling interest in regulating this behavior and that this statute is the most narrowly drawn means of safeguarding that interest. ${ }^{9}$

As that final sentence makes clear, the Eleventh Circuit did not strike down the statute. Rather, the court identified the proper

- Id.

B 425 U.S. 901 (1976), affirming 403 F.Supp. 1199 (E.D. Va. 1975).

7 Hardwick, 760 F.2d at 1204.

- Meyer v. Nebraska, 262 U.S. 390 (1923); Akron v. Akron Center for Reproductive Health, 462 U.S. 416 (1983).

- Hardwick, 760 F.2d at 1210-13, 1212-13. 
standard of review to be used by the district court at trial, where presumably Georgia would seek to prove its "compelling interest" in criminalizing the conduct in question. The standard, applicable whenever a "fundamental" constitutional right is in jeopardy, is a high one, and consequently the state's burden of proof would be extremely onerous. But the appellate court did not take the final step of applying the standard to the statute--such a step would have been premature since the district court had yet to receive any evidence in the case-and the court certainly did not declare the Georgia statute unconstitutional.

It was in that posture that Bowers $v$. Hardwick arrived at the Supreme Court. I mentioned at the outset that the majority in Hardwick upheld the Georgia statute by a vote of five to four; but that fact is less interesting and noteworthy than the manner in which the Court acted. The majority opinion, written by Justice White, is an extremely shoddy bit of work on at least three scores.

First, the issue before the Court was clearly not whether the Georgia statute was constitutional or unconstitutional, but rather which constitutional standard of review the trial court should apply in considering that question. Nonetheless, the five justices in the majority rushed forward to reach the ultimate question of constitutionality, in the absence of any ruling below on that question and in the absence of any record of trial. The Court first rejected the "compelling interest" standard that the Eleventh Circuit had adopted. It then proceeded to decide whether the statute satisfied the other principal constitutional standard of review-the so-called "rational basis" test-and concluded that it did, with almost no consideration of what state interest the Georgia legislature might have seen as rationally related to the statute.

In resolving the issue of constitutionality, the Court undeniably exceeded its authority. It also ignored the long-standing tenet that constitutional decisions, because of their gravity, should be issued only on the basis of a well-developed record and well-framed issues. The majority was apparently so eager to hand down a ruling on sexual privacy that it either overlooked or deliberately disregarded the posture of the case before it. Given the importance of the ultimate constitutional question raised in Hardwick, the majority's zeal is more than improper; it verges on scandalous.

In addition, the majority went out of its way to reformulate the issue presented by the case in order to rebuke homosexual-and only homosexual_-"sodomy." The Georgia statute covers oral or anal intercourse committed by any two people-homosexual or heterosexual, unmarried or married. The two 
courts below dealt with the statute in its entirety; they made no distinctions among categories of individuals subject to the prohibition on sodomy. The Supreme Court, however, characterized the case as one concerning "the fundamental rights of homosexuals," and specifically postponed the issue of the statute's application to "other acts of sodomy." It reframed Hardwick, converting it from a "sexual privacy" case to a "gay rights" case. The Eleventh Circuit had agreed with the trial court that the Does lacked standing, leaving Michael Hardwick as the sole plaintiff, but that court never treated the case as anything other than a full facial attack. Moreover, the complaint in the case challenged the statute fully, not merely as it applied to Michael Hardwick, to the Does, or to anyone else.

The Court should have addressed Bowers $v$. Hardwick as presented by the complaint and by the two lower court opinions. That the majority chose to treat the question as one of an alleged "fundamental right to engage in homosexual sodomy"11 was a surprising innovation; no one else had ever characterized it in that way. The majority's reformulation of Hardwick reinforces the impression that the justices had made up their minds on the proper result beforehand, and then tailored the case to suit their particular prejudices.

Finally, the majority's reasoning on the merits was exceedingly weak. The majority rejected completely the argument, which had convinced the Eleventh Circuit, that the Supreme Court's precedents on privacy imply a general right to "intimate association" of a sexual nature. Instead, the Court recited the familiar litany of privacy cases to date, including in its list decisions that predate the formal recognition of a constitutional right to privacy, and then attached to each case a particular label. ${ }^{12}$ Pierce $v$. Society of Sisters and Meyer $v$. Nebraska, said the majority, dealt with "child rearing and education." Skinner v. Oklahoma concerned "procreation"; Loving v. Virginia, "marriage"; Griswold v. Connecticut and Eisenstadt v. Baird, "contraception"; and Roe v. Wade, "abortion." ${ }^{13}$ After setting forth its list, the majority then merely offered its conclusion:

10106 S.Ct. at 2843,2842 n.2.

11 Id. at 2844.

12 Id. at 2843-44.

13 Pierce v. Society of Sisters, 268 U.S. 510 (1925); Meyer v. Nebraska, 262 U.S. 390 (1923); Skinner v. Oklahoma, 316 U.S. 535 (1942); Loving v. Virginia, 388 U.S. 1 (1967); Griswold v. Connecticut, 381 U.S. 479 (1965); Eisenstadt v. Baird, 405 U.S. 438 (1972); Roe v. Wade, 410 U.S. 113 (1973). 
Accepting the decisions in these cases and the above description of them, we think it evident that none of the rights announced in those cases bears any resemblance to the claimed constitutional right of homosexuals to engage in acts of sodomy that is asserted in this case. No connection between family, marriage or procreation on the one hand and homosexual activity on the other has been demonstrated. ${ }^{14}$

By sorting out cases according to labels adopted in previous decisions, the majority acted in a manner more befitting mail clerks than justices of the Supreme Court. Judges, particularly at the level of the Supreme Court, should apply real analysis to the issues before them. Bowers v. Hardwick is, unfortunately, little more than judgment by pigeonhole. "Sodomy," in the view of the majority, does not fit within the category "child rearing and education." Nor does it come within the terms "procreation," "marriage," "contraception," or "abortion." Therefore, Michael Hardwick loses.

Ipse dixit can never suffice for a decision by the Supreme Court of the United States, and, at bottom, Bowers v. Hardwick is just that. The Court owed the rest of us, who must abide by its pronouncements, an explanation for its decision-particularly when important lower courts, including the Eleventh Circuit and the Court of Appeals of New York State, had interpreted the Court's previous privacy cases to lead to exactly the opposite result. ${ }^{15}$

The decision in Hardwick is particularly difficult to square with Eisenstadt $v$. Baird, in which the Court invalidated a Massachusetts statute forbidding single people from obtaining contraceptives to prevent pregnancy. In effect, Eisenstadt extended the privacy right enunciated in Griswold to the unmarried. The Court, through Justice Brennan, wrote:

If the right of privacy means anything, it is the right of the individual, married or single, to be free from unwarranted governmental intrusion into matters so fundamentally affecting a person as the decision whether to bear or beget a child. ${ }^{16}$

Under Eisenstadt, an unmarried person may choose to engage in sexual conduct with another adult for purposes other than procrea-

14 Hardwick, 106 S.Ct. at 2844.

${ }^{16}$ Hardwick, 760 F.2d 1202; People v. Onofre, 51 N.Y.2d 476, 415 N.E.2d 936, 434 N.Y.S.2d 947 (1980).

1e 405 U.S. at 453. 
tion, and the government may not interfere with that decision. That is precisely the choice made by Michael Hardwick on the night he was arrested. It is not sufficient for the Court to distinguish Eisenstadt from Hardwick merely by invoking the term "contraception" to describe the earlier case. At bottom, the two cases concern the same activity. If the Court believed otherwise, it should have explained precisely why. Semantics alone will not do.

In contrast to the majority's opinion, the four dissenters in Hardwick, under Justice Blackmun's lead, attempted to formulate a theory to fill in the gaps left by the previous cases on privacy. "I believe," Justice Blackmun wrote, "we must analyze [Hardwick's] claim in the light of the values that underlie the constitutional right to privacy." The most significant value he discerned from the previous cases was "the fundamental interest all individuals have in controlling the nature of their intimate associations with others." He also inferred from those cases two different aspects of privacy: a "decisional aspect" that pushes certain decisions beyond the reach of government intrusion, and a "spatial aspect" that protects certain places, such as the home. He concluded that both aspects of privacy were implicated in Hardwick; he then determined that the Georgia statute should be subject to strict scrutiny in that Hardwick's action "involves no real interference with the rights of others, for the mere knowledge that other individuals do not adhere to one's value system cannot be a legally cognizable interest ... let alone an interest that can justify invading the houses, hearts and minds of citizens who choose to live their lives differently."17

The majority, to reinforce its conclusion, put forward the undeniable fact that sodomy statutes are very old. "Proscriptions against that conduct have ancient roots," wrote Justice White. ${ }^{18}$ But the Court's reliance on history in Hardwick is only another manifestation of its unprincipled approach to the case. In past privacy cases, the Court has felt at liberty to depart from history when the interest at stake seemed sufficiently important. In Loving v. Virginia, for example, it invalidated a statute forbidding miscegenation despite the fact, noted by the Court, that marriage between partners of different races traditionally had been prohibited by most states in the country. In Roe v. Wade, the Court inferred a right to abortion from the Constitution even though abortions had been criminally prohibited in virtually every state for decades. In

17106 S.Ct. at $2848,2850-53,2856$.

${ }^{18}$ Id. at 2844. 
the Court's modern past, the mere longevity of a statute, even when the law fits into a legal pattern or "tradition," has never before been deemed a bar to judicial intervention.

The majority's abhorrence for Michael Hardwick's sexual activities blinded it to the need to explain how Georgia's dislike for "deviant" sexual conduct constituted even a minimally rational basis for the statute. The critical constitutional question in Hardwick was not what Michael Hardwick was doing in his bedroom, but rather what the state of Georgia was doing there. To answer this question, Justice White offered only "the presumed belief of a majority of the electorate in Georgia that homosexual sodomy is immoral and unacceptable." He glibly remarked that "law is constantly based on notions of morality, and if all laws representing essentially moral choices are to be invalidated under the Due Process Clause, the courts will be very busy indeed."18 But courts should be busy when laws threaten fundamental rights protected by the Constitution. If Justice White's quip is the new law, the courts will have very little to do in the name of the fourteenth amendment.

The Court was willing to overturn legislative acts based on "essentially moral choices" when it struck down laws prohibiting contraceptive sales and abortion. Why should Bowers $v$. Hardwick be different? What is it about the claim in Hardwick that sets it apart from other privacy claims? The utter lack of reasoning in the majority's opinion, in tandem with the procedural manipulation of the case, strongly suggests that the explanation lies in the emotional response of five justices to the subject matter underlying the case as they perceived it, or rather, as they reconstituted it: the subject of homosexuality.

The tone of the opinion also leads to this conclusion. At one point, the majority resorted to a flippancy verging on contempt; it described Michael Hardwick's invocation of constitutional protection as "at best, facetious." The four dissenters also may have believed that antipathy to homosexuality was at the root of the majority's decision, for their opinion contains a caustic reference to the Court's "almost obsessive focus on homosexual activity."2o

Justice White and his four colleagues, it seems, simply do not like homosexuality, and do not want to elevate or honor it by conferring on it the imprimatur of the Constitution of the United States. As citizens, they are entitled to their point of view, however

19 Id. at $2846,2846$.

20 Id. at 2846 (majority), 2849 (dissent). 
unfair or unreasoned it may be. But as judges of the highest court in the land, they have a higher obligation than ordinary citizens. They have a duty to look beyond their personal disapproval in interpreting the Constitution.

Bowers $v$. Hardwick is, fundamentally, lawmaking by personal predilection-precisely the sort of judicial self-indulgence that the critics of the Warren Court most often decry. It is a cavalier decision, without reference to either standard or principle and in blatant disregard of well-settled procedural rules.

Just two years ago, in City of Cleburne v. Cleburne Living Center, the same Court, in another opinion by Justice White, struck down a decision by a small city in Texas to deny a zoning permit to a home for the mentally retarded as based solely upon "mere negative attitudes, or fear, unsubstantiated by factors which are properly cognizable in a zoning proceeding." 21 In invalidating the city's action as a violation of equal protection, the Court was performing once again its most important function: counterbalancing the excesses of the elective branches of government, whether federal or state, by reference to the Constitution, the charter against which all acts of government are to be measured. In Hardwick, the Court did more than abdicate that role; the Court itself became the engine of abuse by surrendering to, and then giving voice to, the prejudices of its own members in precisely the manner condemned by Cleburne.

The implications of the Hardwick case far transcend either Michael Hardwick or the homosexual Americans for whom he speaks. They should trouble anyone who believes in the rule of law. 